\title{
ANALISIS MOTIVASI BELAJAR PESERTA DIDIK KESULITAN BERHITUNG PERMULAAN
}

\author{
Derista Lidya Carolina $^{\left.a^{*}\right)}$, Nurlinda Safitri $^{a)}$, Elly Sukmanasa $^{a)}$ \\ ${ }^{a)}$ Universitas Pakuan, Bogor, Indonesia \\ *) e-mail korespondensi: carolinaderista@gmail.com
}

\section{Riwayat Artikel}

diterima 25 Agustus 2020 direvisi 03 September 2020 disetujui 12 September 2020

\begin{abstract}
Abstrak
Kesulitan dalam menyelesaikan perhitungan kerap dialami peserta didik dalam pembelajaran. Salah satunya pada seorang peserta didik yang mengalami kesulitan dalam berhitung permulaan seperti menyelesaikan penjumlahan, pengurangan, perkalian dan juga pembagian yang perlu dianalisis motivasi pada peserta didik tersebut. Sehingga penelitian ini bertujuan untuk mengetahui motivasi belajar peserta didik kesulitan berhitung permulaan pada seorang peserta didik kelas VB di SDN Genteng Kota Bogor.Penelitian ini dilaksanakan menggunakan jenis Pendekatan Penelitian Kualitatif Sudi Kasus. Pada pelaksanaannya, teknik pengumpulan dan perekaman data yang digunakan peneliti yakni secara triangulasi penggabungan informasi antara hasil observasi dan juga wawancara dan dokumentasi. Penelitian ini dilaksanakan pada Semester Genap Tahun Ajaran 2019/2020. Hasil penelitian ini menunjukkan ada faktor internal dan eksternal yang mempengaruhi motivasi belajar peserta didik kesulitan berhitung tersebut. Peserta didik ini memiliki jumlah nilai paling kecil ketika Penilaian Tengah Semester dibandingkan dengan teman sekelasnya. Meskipun begitu, peserta didik kesulitan berhitung memilliki kelebihan dan keuninkan pada saat bernyanyi. Suaranya yang merdu dan bagus membuat setiap orang yang mendengarnya merasa takjub. Selain bernyanyi lagu jenis pop, peserta didik ini memiliki suara indah dalam tilawah. Karena peserta didik tersebut mengikuti kegiatan marawis dan menjadi seorang vocalis.
\end{abstract}

Kata kunci: motivasi belajar; kesulitan berhitung permulaan.

\begin{abstract}
ANALYSIS OF STUDENTS 'LEARNING MOTIVATION IN DIFFICULTY CALCULATING THE BEGINNING

Abstract. Difficulty in completing calculations is often experienced by students in learning. One of them is a student who has difficulty in preliminary counting such as completing addition, subtraction, multiplication and division that needs to be analyzed the motivation of these students. So that this study aims to determine the learning motivation of students who have difficulty counting at the beginning of a class VB student at SDN Genteng, Bogor City. This research was conducted using a case study qualitative research approach. In practice, the data collection and recording techniques used by researchers are triangulation of combining information between observations and interviews and documentation. This research was conducted in the Even Semester of the 2019/2020 Academic Year. The results of this study indicate that there are internal and external factors that affect the learning motivation of students who have difficulty in arithmetic. These students have the smallest number of scores during the Mid-Semester Assessment compared to their classmates. Even so, students who have difficulty counting have advantages and are uniqueness when singing. Her beautiful voice made everyone who heard it amazed. Apart from singing pop songs, these students have beautiful voices in recitations. Because these students take part in marawis activities and become vocalists.
\end{abstract}

Keywords: Learning Motivation and Difficulty Beginning

\section{PENDAHULUAN}

Setiap orang tua tentunya menginginkan kualitas pendidikan yang terbaik untuk anaknya. Salah satu lingkungan pendidikan yaitu di sekolah. Kegiatan pembelajaran yang inovatif dan kreatif diharapkan mendukung keberhasilan dalam pembelajaran. Peranan orang tua salah satunya menjadi peran mendasar bagi tumbuh kembangnya motivasi bagi peserta didik untuk belajar.

Motivasi internal atau motivasi yang tumbuh dari dalam diri sendiri harus tetap ada. Sedangkan motivasi yang bersifat dari luar atau external pun tidak kalah mendukung guna menumbuhkan dorongan. Setiap peserta didik tentunya dilahirkan berbeda- beda, memiliki karakteristik masing- masing dan memiliki keunikan dalam dirinya yang berbeda satu sama lain. Dalam dunia pendidikan peserta didik ada yang mampu menyelesaikan tugas yang diberikan oleh guru secara cepat atau pun lamban. Tidak jarang bagi peserta didik yang mengalami kesulitan dalam pembelajaran akan sedikit tertinggal dengan temantemannya yang lain. 
Akronim kata Calistung sepertinya sudah tidak asing lagi di dengar, akronim ini merupakan kependekan dari Membaca, Menulis dan Menghitung. Berbicara tentang Calistung salah satu bagiannya yaitu berhitung. Kemampuan berhitung tentu saja sudah ada dari proses pembelajaran di tingkat dasar. Bahkan ketika peserta didik memasuki sekolah TK atau PAUD berhitung sudah di ajarkan dan bukan lagi kegiatan pembelajaran yang baru. Namun dalam penerapannya peserta didik ada yang lamban dan cepat dalam proses pembelajaran tersebut. Tentu dengan naiknya tingkat jenjang pendidikan materi yang berhubungan dengan cara penghitungan juga semakin bertambah tingkatan kesukarannya. Umumnya kegiatan berhitung terdapat pada pelajaran matematika.

Bila di tinjau dari penelitian terdahulu tentang motivasi belajar, yaitu penelitian yang dilaksanakan oleh Isnaini Wijayani [1] tentang Hubungan Motivasi Belajar Dengan Prestasi Belajar Peserta didik Kelas V SDN 1 Waringinsari Barat, bahwa apabila motivasi belajar peserta didik baik maka prestasi belajar yang diperoleh peserta didik juga akan baik, sedangkan apabila motivasi belajar peserta didik masih kurang baik maka prestasi belajar yang diperoleh peserta didik akan kurang baik pula. Bentukbentuk motivasi belajar seseorang terdiri dari motivasi yang terdapat di dalam diri peserta didik dan motivasi dari luar diri peserta didik.

Peneliti telah melakukan observasi yang dilaksanakan di salah satu sekolah di Kota Bogor yaitu SDN Genteng yang berada di Jalan Raya Genteng Kota Bogor Kecamatan Bogor Selatan. Penelitan ini bertujuan untuk menganalisis motivasi belajar yang ada pada seorang peserta didik kelas VB yang mengalami kesulitan dalam belajar berhitung permulaan. Observasi di masa pandemi ini dilakukan secara online dan dengan datang langsung menyambangi peserta didik tersebut di kediamannya.

Subjek yang diteliti berinisial $\mathrm{P}$ merupakan salah satu peserta didik kelas VB yang lahir di Bogor pada 1 Januari 2009. Ayahnya bekerja sebagai penyanyi di sebuah tempat karoke di Jakarta sementara ibunya bekerja sebagai asisten rumah tangga dan bertempat tinggal di Jalan Dekeng Jaya. Peneliti melihat bahwa terdapatnya kesulitan pada peserta didik tersebut saat dihadapkan dengan kegiatan pembelajaran yang berupa penghitungan. Khususnya dalam proses penempatan serta penghitungan. Kurang telitinya dengan penguasaan konsep penempatan hitungan menjadi kesulitan peserta didik P. Bahkan untuk menghitung sederhana seperti penjumlahan, pengurangan, perkalian dan pembagian tidak mampu ia lakukan dengan tepat.

Motivasi menjadi memiliki peranan yang sangat penting dalam kelangsungan pembelajaran. Motivasi yang tertanam pada diri peserta didik dapat menumbuhkan semangat belajar yang besar. Ngalimun [2] berpendapat bahwa motivasi adalah aspek yang sangat penting untuk membelajarkan peserta didik. Motivasi bisa diartikan sebagai suatu pendorong seorang peserta didik untuk bertindak dan melakukan sesuatu.
Motivasi bisa menjadi sebuah penggerak dalam melakukan perubahan yang ada pada diri seseorang. Sejalan dengan pendapat yang dipaparkan oleh Majid [3] motivasi adalah energi aktif yang menyebabkan terjadinya suatu perubahan pada diri seseorang yang tampak pada gejala kejiwaan, perasaan dan juga emosi sehingga mendorong individu untuk bertindak maupun melakukan sesuatu dikaranakan adanya tujuan, kebutuhan, atau keinginanyang harus terpuaskan.

Adapun pendapat yang selaras disampaikan oleh Dimyati dan Mudjiono [4] motivasi belajar ialah kekuatan mental yang berdampak mendorong terjadinya proses pembelajaran. Ketika seseorang tidak memiliki motivasi yang tertanam pada dirinya, tentu hal yang dihadapi adalah sebuah kemalasan untuk bergerak. Sardiman yang dikutip oleh Wulandari [5] motivasi pada suatu pembelajaran ialah sebagai keseluruhan daya yang menjadi penggerak di dalam diri peserta didik yang menimbulkan suatu kegiatan belajar, yang menjamin kelangsungan dari kegiatan belajar, sehingga tujuan yang diharapkan akan terwujud.

Sumber dari motivasi yang ada pada diri sesorang berasal dari dalam dan luar dirinya. Sejalan dengan pendapat Uno dalam Nawawi [6] motivasi belajar adalah dorongan internal dan eksternal pada peserta didik yang sedang belajar untuk mengadakan perubahan tingkah laku, pada umumnya dengan beberapa indikator atau unsur yang mendukung. Selain motivasi, hal yang terkadang menjadi hambatan dalam proses pembelajaran ialah peserta didik memiliki kesulitan belajar, salah satunya ialah kesulitan dalam berhitung. Menurut Sukmanasa, Lina dan Junidi [7] kesulitan berhitung juga disebut Diskalkulia. Kesulitan belajar berhitung yang berat disebut Alkakulia. Ada tiga elemen belajar berhitung yang harus dikuasai oleh peserta didik. Ketiga elemen tersebut adalah konsep, komputasi dan pemecahan masalah. Sedangkan pendapat yang dikemukakan oleh Fadhli [8] yaitu Diskalkulia dikenal juga dengan isitialh "math diffculty" karena menyangkut gangguan pada kemampuan kalkulasi secara matematis.

Kesulitan dalam berhitung juga dikategorikan sebagai gangguan dalam kegiatan pembelajaran. Sejalan dengan pendapat Widyorini dan Julia [9] Diskalkulia adalah gangguan pada pelajaran berhitung. Berhitung adalah merupakan bagian dari kemampuan dimensi atau pandang ruang dan berpikir ilmu matematika, yang mensyaratkan peserta didik siap untuk mengerjakan kali-bagi-tambahkurang yang membutuhkan kemampuan sistem abstraksi.

Berbagai kesulitan dalam berhitung dikategorikan menjadi beberapa bagian yakni dikutip dari Suryani [10] mengungkapkan bahwa kesulitan berhitung adalah kesulitan dalam menggunakan bahasa simbol untuk berpikir, mencatat, dan mengkomunikasikan ide- ide yang berkaitan dengan kuantitas atau jumlah. Kesulitan berhitung tentunya membuat peserta didik mengalami ketidakmampuan dalam mempelajari konsep perhitungan dengan tepat. Putri dan Hutami dalam Arisandi [11] kesulitan berhitung matematika (diskalkulia) adalah kesulitan belajar yang menyebabkan peserta didik menjadi 
tidak bisa berhitung. Mengalami kesulitan dalam memahami konsep matematika.

\section{METODE PENELITIAN}

Penelitian yang dilaksanakan peneliti menggunakan jenis pendekatan penelitain kualitatif studi kasus, Penelitian dilaksanakan di Sekolah Dasar Negeri Genteng Bogor Jalan Dekeng No.42, Kecamatan Bogor Selatan, Kota Bogor. Subjek penelitian adalah seorang peserta didik kelas VB kesulitan berhitung, orangtua peserta didik dan guru kelas VB di Sekolah Dasar Negeri Genteng Bogor Semester Genap Tahun Pelajaran 2019/2020.

Penelitian kualitatif adalah suatu pendekatan yang juga disebut pendekatan investigasi karena biasanya peneliti mengumpulkan data dengan cara bertatap muka langsung dan berinteraksi dengan subyek ditempat penelitian. Dengan pendekatan kualitatif ini peneliti akan menggambarkan dan menganalisis setiap individu atau sekelompok kecil dalam kehidupan dan pemikirannya. Penelitian kualitatif ini melibatkan serta menggali informasi yang ada melalui seorang peserta didik, orangtua peserta didik dan guru kelas VB.

Alur prosedur penelitian kualitatif yang akan dilaksanakan pada penelitian ini mekanismenya dimulai dari tahap perencanaan dimana hal ini ditujukan untuk mempertajam fokus perumusan permasalahan, selanjutnya dengan melakukan observasi, wawancara dan dokumentasi. Tahap analisis juga pengecekan keabsahan data perlu dilakukan selanjutnya untuk menemukan temuan yang baru. Selanjutnya penarikan kesimpulan dari penelitian yang telah dilaksanakan.Teknik pengumpulan dan perekaman data yang digunakan peneliti yakni secara triangulasi penggabungan informasi antara hasil observasi dan juga wawancara dan dokumentasi.

\section{HASIL DAN PEMBAHASAN}

Temuan Penelitian merupakan data hasil penelitian yang bersifat kualitatif yang disusun sesuai urutan fokus dan subfokus penelitan; apa yang ditemukan pada hasil analisis data, agar dideskripsikan. Berdasarkan Analisis Informasi Informan menunjukan bahwa peserta didik yang menjadi subjek dalam penelitian ini memiliki motivasi belajar yang cukup baik pada dirinya. Meskipun masih sering merasa mengeluh bahwa ia tidak mampu melakukan perhitungan dan menyerah dalam mengerjakan soal-soal yang berhubungan dengan perhitungan yang cukup sederhana.

Subjek memiliki minat dalam pembelajaran matematika, tetapi memang tidak terlalu menyukai pelajaran tersebut. Apalagi jika berkaitan dengan soal cerita yang dirasa sulit untuk dikerjakan. Ketika pembelajaran les secara bersama-sama subjek selalu bersemangat, tetapi terkadang malals mengerjakan tugas sekolah. Sujek merupakan peserta didik yang memiliki nilai matematika paling rendah di kelasnya yakni dengan skor 46. Serta jumlah nilai mata pelajaran yang dia dapatkan juga paling rendah di kelasnya yakni sebesar 491 .

Ketika peserta didik diberikan hadiah oleh orang lain seperti guru, ia merasa lebih bersemangat dalam belajar. Guru tidak pernah memberikan hukuman kepada peserta didik tersebut dengan cara memberikan tugas yang banyak, hanya berupa dari segi nasihat saja atau menulis di buku tidak akan mengulangi kesalahan yang telah peserta didik lakukan. Tetapi subjek tidak pernah mengalami hukuman tersebut. Kondisi lingkungan kurang mendukung karena agak berisik akibat rumah yang berdekatan dengan tetangga, tetapi lingkungan di sekolah dirasa cukup kondusif untuk belajar.

Peserta didik tidak mampu mengerjakan soal perhitungan sederhana, seperti beberapa soal berikut:

$$
\begin{aligned}
& \text { 1) } 979 \text { 2) } 79 \quad \text { 3) } 5 \times 6=\ldots . \text { 4) } 9: 3=\ldots . \\
& \frac{797}{\ldots \ldots .}+\frac{65}{\ldots \ldots .}-
\end{aligned}
$$

Jawaban yang diberikan salah semua. Terkadang proses pengerjaan soal tidak sesuai dengan cara perhitungan yang tepat dalam matematika. Hal ini menyebabkan kesalahan dalam jawaban. Kesulitan belajar dalam berhitung sangat dirasakan oleh subjek, pihak sekolah seperti guru pun telah melakukan upaya agar subjek dapat memahai perhitungan. Tetapi jawaban yang diberikan subjek dalam mengisi soal perhitungan selalu salah.

Pada saat pelaksanaan kegiatan observasi, peserta didik antusias dan bersemangat mengikuti les bersama yang dilakukan didampingi oleh peneliti. Peserta didik berusaha untuk mencoba mengerjakan soal yang diberikan, tetapi memang intelektual yang kurang dimiliki oleh peserta didik menghambat pemahaman konsep terhadap perhitungan. Meskipun peserta didik memiliki kekurangan dalam bidang akademik, tetapi ia memiliki potensi dalam bidang non akademik. Seperti dalam kegiatan marawis.

Kegiatan observasi yang dilaksanakan oleh peneliti dilakukan dengan cara melaksanakan les atau bimbingan belajar pada peserta didik kesulitan berhitung. Pada proses itulah peneliti dapat melihat kegiatan pelaksanaan pembelajaran pada peserta didik. Kegiatan ini dilaksanakan tidak hanya dengan subjek sendiri saja, tetapi dengan melibatkan beberapa teman di lingkungan rumah peserta didik yang masih satu kelas maupun berbeda tingkatan kelas jenjang sekolah dasar. Hal ini dilakukan sebagai upaya menghilangkan rasa tidak percaya diri dan mengisi kegiatan agar bisa sambil belajar bersama dimasa pandemi seperti ini. Sehubungan dengan kegiatan pembelajaran di sekolah yang diliburkan.

Setelah melaksanakan serangkaian kegiatan penelitian mulai dari prapenelitian dan observasi. Kegiatan penelitian selanjutnya dilaksanakan dengan melakukan kegiatan wawancara pada informan pertama yakni peserta didik.

Berdasarkan hasil dari wawancara bersama peserta didik kesulitan berhitung permulaan didapatkan informasi bahwa peserta didik menyukai pelajaran matematika tetapi tidak terlalu suka seperti perkalian karena peserta didik tersebut masih kesulitan bagaimana penempatan angka 
yang tepat. Wali kelas pernah memberikan hadiah berupa es dan peserta didik mengaku merasa senang. Salah satu penelitian terkait tentang pemberian hadiah atau reward ialah hasil penelitian yang dilaksanakan oleh Winarsih [12] dengan judul Upaya Guru Dalam Mengatasi Kesulitan Belajar Membaca, Menulis Dan Berhitung (Calistung) Pada Peserta didik Kelas 1 SD Negeri Jatiroto,Wonosari, Purwosari, Girimulyo, Kulon Progo. Hasil penelitian ini menunjukan bahwa upaya yang dilakukan guru kelas 1 SD Negeri Jatiroto untuk mengatasi kesulitan belajar calistung yaitu dengan penggunaan metode belajar yang bervariasi, menciptakan lingkungan belajar yang efektif dan kondusif, les tambahan dan pemberian reward.

Kemudian hasil wawancara selanjutnya ditemukan bahwa peserta didik merasa ragu dan sering kesulitan untuk menyelesaikan soal perhitungan karena tidak paham dan lupa konsep cara perhitungan.

Selanjutnya kegiatan wawancara yang ke dua dilaksanakan bersama Ibu peserta didik kesulitan berhitung. Berdasarkan hasil wawancara yang telah dilaksanakan, ditemukan beberapa informasi bahwa dukungan semangat selalu diberikan oleh Ibu peserta didik, salah satunya dengan meminta peserta didik untuk belajar bersama dengan teman- teman lingkungan tempat tinggalnya karena ibunya yang bekerja sehingga tidak bisa mengajarkan dan menemani untuk belajar. Karena ibunya tidak bisa mengontrol setiap waktu, maka dalam kegiatan mengerjakan tugas sekolah atau PR ia mengerjakannya sendiri berbekal dari handphone yang dimiliki untuk mencari jawaban dari internet (google).

Kondisi Informasi pembelajaran di sekolah terkadang terkendala karena handphone yang sering di bawa ibunya bekerja. Sehingga informasi berkaitan dengan tugas sekolah di masa pandemi ini terkadang diberikan oleh teman sekelasnya yang masih bertetangga. Dalam hal ketelitian sebenarnya peserta didik teliti namun masih suka mengeluh tidak mengerti sehingga jawabannya salah. Ibunya mengungkapkan bahwa beliau tidak bisa mengajarkan peserta didik karena pendidikannya kurang. Terutama pembelajaran matematika karena tidak mengerti dan kurang paham. Sehingga meminta peserta didik bertanya kepada temannya. Ibunya terus terang peserta didik tidak bisa menghitung dan kurang lancar yang terkadang salah.

Kegiatan wawancara ketiga melibatkan Bapak dari peserta didik. Beliau menuturkan bahwa semangat dan support selalu diberikan. Bapaknya mengaku sudah mendidik dengan keras namun dirasa IQnya anaknya memang belum bagus. Nasihat untuk selalu rajin belajar selalu diberikan. Peserta didik sering bertanya kepada Bapaknya ketika mengerjakan PR, tetapi beliau menuturkan terkadang merasa kebingungan jika tidak tahu bagaimana cara mengerjakan PR itu. Meskipun begitu, peserta didik tergolong anak yang rajin dalam hal pekerjaan rumah.

Hasil wawancara dari sumber atau informan terakhir ialah berdasarkan hasil wawancara yang telah dilaksanakan bersama wali kelas didapatkan informasi bahwa sebagai seorang guru yang menjadi wali kelas VB tentunya beliau memberikan dukungan berupa semangat yang pertama yakni memotivasi agar peserta didik pandai berhitung. Pemberian konsep perhitungan pada subjek membutuhkan waktu yang cukup lama, tetapi jika sudah dikumpulkan pun tugas tersebut masih tetap salah. Guru mengambil kesimpulan bahwa masalah intelegensi kembali kepada kemampuan anak itu sendiri. Ada yang memang sudah dasarnya oleh Allah diberi pintar, ada yang pintar perlu proses untuk terus diberi pembinaan dan latihan terus menerus.

Selain itu guru memberi informasi mengenai kelebihan yang dimiliki oleh peserta didik kesulitan berhitung. Peserta didik tersebut berani tampil untuk dibidang seni, ketika ada lomba- lomba perserta didik mau dan mengajukan dirinya. Kelebihan yang dimiliki oleh peserta didik tersebut lebih kepada kemampuan non akademik. Salah satu contohnya yang lain ialah kelebihan peserta didik ketika mengikuti kegiatan marawis yang cukup bagus hanya saja memang dalam hal kemampuan akademiknya yang masih dikategorikan kurang.

Hal yang mempengaruhi motivasi belajar peserta didik yakni ada dari faktor internal dan faktor eksternal . Faktor internal yakni yang berasal dari dalam diri peserta didik itu sendiri. Salah satunya ialah kemauan peserta didik yang cukup besar hal ini terbukti dengan adanya data yang berkesinambungan antara hasil observasi dan juga wawancara yang sebelumnya telah peneliti laksanakan. Selain itu faktor eksternal yakni faktor yang berasal dari luar peserta didik diantaranya faktor lingkungan rumah yang kurang mendukung, peseta didik terkadang lupa waktu karena bermain dengan teman-temannya, faktor lingkungan yang kurang kondusif menjadikan peserta didik sulit berkonsentrasi untuk belajar. Serta faktor dari basic guru yang berbeda juga menjadikan guru mengalami kekurangan pada saat penyampaian materi.

Pada kegiatan penelitian yang telah dilaksanakan oleh peneliti ditemukannya penyebab dari unsur eksternal mengapa peserta didik memiliki kesulitan berhitung. Faktor eksternal salah satunya berasal dari orangtua peserta didik yang tidak mampu mengawasi anaknya dalam kegiatan pembelajaran secara maksimal. Karena orangtua yang bekerja sehingga kurangnya pengawasan dari kedua orangtuanya. Selain itu, peserta didik hanya mengandalkan kunci jawaban yang berasal dari internet. Sehingga apabila mengalami kesulitan hanya bergantung kepada internet. Peserta didik melakukan copy paste terhadap jawaban soal yang ada di internet.

Maka dari itu, ini dapat mengakibatkan peserta didik menjadi tergantung pada jawaban dari internet untuk mengerjakan soal- soal yang diberikan oleh guru. Hal ini tentu saja menyebabkan peserta didik tidak mampu mengembangkan pemikirannya dalam mengerjakan soal dalam pemecahan masalah. Pendidikan orangtua yang kurang juga menjadi salah satu faktor eksternal yang menyebabkan peserta didik mengalami kesulitan berhitung dalam pembelajaran. Sehingga tidak adanya wadah bagi peserta didik untuk bertanya mengenai kesulitan yang ia hadapi selain di sekolah. 
Perlu adanya upaya dan penanganan yang tepat bagi peserta didik merupakan sebuah cara yang dapat membantunya dalam mengoptimalkan cara menghadapi kesulitannya dalam pembelajaran khususnya berhitung. Bisa menggunakan jasa guru les privat ataupun pendampingan pada saat mengerjakan soal latihan. Pengulangan materi yang dilakukan oleh guru pun terkadang tetap saja peserta didik tersebut tidak bisa menjawab. Ketika ia sudah berusaha menjawab dengan durasi yang lebih lama, hasilnya kerap saja jawaban yang diberikan lebih banyak salah.

Fakta ini sesuai dengan teori Azhari dalam Mutiani dan Suyadi [13] Penyebab diagnosa diskalkulia (gangguan belajar matematika) kesulitan berhitung dapat digolongkan ke dalam faktor internal dan faktor eksternal. Faktor internal terdapat, kemampuan pengetahuan, motivasi, atensi, sikap, kebiasaan belajar, dan kondisi fisik. Sedangkan faktor eksternal terdapat lingkungan sekolah, lingkungan keluarga dan lingkungan masyarakat.

Selain itu fakta ini sesuai dengan teori Dimyati dan Mudjiono [4] menyatakan implikasi prinsip motivasi bagi peserta didik adalah didasarinya oleh peserta didik bahwa motivasi belajar yang ada pada diri mereka harus dibangkitkan dan mengembangkan motivasi belajar mereka secara terus- menerus, peserta didik dapat melakukannya dengan menentukan/ mengetahui tujuan belajar yang hendak dicapai, menanggapi secara positif pujian/dorongan dari orang lain, menentukan target/sasaran penyelesaian tugas belajar dan perilaku sejenis lainnya.

Motivasi internal yang ada pada diri peserta didik kesulitan berhitung sudah cukup baik, tetapi motivasi eksternal yang dirasakan peserta didik masih kurang. Hal ini menjadikan hasil belajar mengenai pembelajaran dengan aspek berhitung kurang. Karena kurangnya pengawasan orang tua ketika pelaksanaan pembelajaran di rumah yang disebabkan karena kesibukan orangtua yang sama-sama bekerja.

Hasil penelitian ini sejalan dengan penelusuran terhadap berbagai literatur hasil penelitian yang relevan, peneliti menemukan beberapa hasil penelitian yang terkait dengan judul penelitian yang peneliti angkat. Beberapa hasil penelitian terkait yaitu berdasarkan penelitian yang dilakukan Elvina Bastari [14] dengan judul Penelitian Hubungan Motivasi Belajar dengan Hasil Belajar Peserta Didik Pada Mata Pelajaran IPS Kelas IV SD Negeri 1 Sukabumi Indah Bandar Lampung. Berdasarkan hasil penelitian yang ditunjukan dengan analisis data dan dari pembahasan maka peneliti menyimpulkan bahwa Terdapat hubungan yang positif dan signifikan antara motivasi belajar dengan hasil belajar peserta didik mata pelajaran IPS kelas IV SD Negeri 1 Sukabumi Indah Bandar Lampung Tahun Ajaran 2018/2019. Tingkat korelasi atau Hubungan Motivasi Belajar dan Hasil Belajar Peserta didik Kelas IV Mata Pelajaran IPS Sekolah Dasar Negeri 1 Sukabumi Indah Bandar Lampung Tahun Ajaran 2018/2019 termasuk dalam kategori "kuat".

Selanjutnya penelitian yang dilaksanakan oleh Pamungkas dan Jana [15] Fakultan Keuruan dan Ilmu
Pendidiakn Universitas PGRI Yogyakarta dengan judul Workshop Penanganan Siswa Ksulitan Belajar Menghitung (Dyskalkulia) Pada Mata Pelajaran Matematika. Hasil penelitian dalam workshop ini menunjukkan bahwa perlunya guru terlatih menyusun program pembelajaran individual bagi peserta didik kesulitan berhitung yang mereka alami sebagai alternatif solusi mengatasi kesulitan berhitung peserta didik dan salah satu upaya memberikan layanan pendiidkan sesuai kemampuan dan kebutuhan peserta didik.

Penelitian oleh Maretha Ulia Savira [16] Program Studi Bimbingan dan Konseling Islam Universitas Islam Negeri Sunan Ampel Surabaya dengan judul Teknik Reinforcement Untuk Meningkatkan Motivasi Pada Anak Tunagrahita yang Mengalami Kesulitan Menghitung (dyscalculia learning) di SDN Bendul Merisi 408 Surabaya. Hasil penelitian ini menunjukkan bahwa terjadi perubahan motivasi untuk belajar menghitung meskipun masih perlu arahan dan bimbingan. Pemberian reward dapat bertujuan untuk membantu menumbuhkan motivasi dan menciptakan perilaku yang sama agar konseli mengerjakan apa yang diperintahkan untuk memperoleh reward.

Selanjutnya penelitian yang dilakukan oleh Khusnul Yusvidha Ernata [17] Program Studi Pendidikan Jasmani Kesehatan dan Rekreasi IKIP Budi Utomo Malang dengan judul Analisis Motivasi Belajar Peserta Didik Melalui Pemberian Reward dan Punishment di SDN Ngaringan 05 Kec. Gandusari Kab. Blitar. Hasil penelitian menjelaskan bahwa pemberian reward dan punishment harus disesuaikan dengan situasi dan kondisi peserta didik. Sehingga memberikan motivasi bagi peserta didik uang mengalami kondisi prestasi menurun. Guna merangsang atau memunculkan mmotivasi dalam diri peserta didik sehingga hasil belaajar yang diperoleh semakin meningkat.

Berdasarkan hasil penelitian oleh Mardika [18] dengan judul Analisis Faktor-faktor Kesulitan Membaca, Menulis dan Berhitung Siswa Kealas 1 SD. Hasil penelitian menunjukkan bahwa pembelajaran membaca, menulis dan berhitung di pengaruhi oleh faktor peranan orangtua yang kurang memperhatikan anaknya. Pendampingan orangtua dalam kegiatan belajar di rumah juga mempengaruhi kesulitan peserta didik dalam berhitung. Strategi yang dapat dilakukan guru dengan terus sabat memberikan materi pembelajaran mulai dari dasar sampai peseta didik lancar. Selain itu kerjasama antar orangtua diperlukan untuk mengatasi peserta didik yang mengalami kesulitan berhitung.

\section{KESIMPULAN}

Setelah melalui serangkaian proses penelitian mulai dari observasi, wawancara dan pengumpulan dokumentasi serta data. Maka didapatkan temuan hasil lapangan tentang analisis motivasi belajar perserta didik kesulitan berhitung permulaan kelas VB di Sekolah Dasar Negeri Genteng Kota Bogor dapat ditarik simpulan yakni ada faktor internal dan eksternal yang mempengaruhi motivasi belajar peserta 
didik kesulitan berhitung tersebut. Hanya saja peran eksternal dari orangtua masih kurang, sehingga kurangnya melakukan pengawasan karena sibuk bekerja. Peserta didik memilliki kelebihan dan keuninkan pada saat bernyanyi. Selain bernyanyi lagu jenis pop, peserta didik ini memiliki suara indah dalam tilawah. Karena peserta didik tersebut mengikuti kegiatan marawis dan menjadi seorang vocalis.

\section{REFERENSI}

[1] Wijayani, Isnaini. 2017. Hubungan Motivasi Belajar Dengan Prestasi Belajar Peserta didik Kelas V SDN 1 Waringinsari Barat. Skripsi Pendidikan Guru Sekolah Dasar Universitas Lampung

[2] Ngalimun. 2018. Strategi dan Model Pembelajaran. Yogyakarta: Aswaja Pressindo

[3] Majid, Abdul. 2015. Strategi Pembelajaran Bandung: PT Remaja Rosdakarya

[4] Dimyati dan Mudjiono. 2013. Belajar dan Pembelajaran. Jakarta: Rineka Cipta

[5] Wulandari, Puspa. 2014. Hubungan Antara Lingkungan Belajar, Kemandirian Belajar,Motivasi Belajar dan Prestasi Belajar Siswa Pada Mata Pelajaran Akuntansi.Skripsi Jurusan Pendidikan Ilmu Pengetahuan Sosial Universitas Santa Dharma Yogyakarta

[6] Nawawi,Khoiru. 2016. Pengaruh Kebiasaan Belajar Dan Motivasi Belajar Terhadap Hasil Belajar Siswa Kelas V SD Gugus Dewi Sartika dan Gugus Hasanudin Kota Tegal. Skripsi Jurusan Pendidikan Guru Sekolah Dasar Universitas Negeri Semarang

[7] Sukmanasa, Elly., Lina Novita, dan Junidi.2019. Pengantar Pendidikan Anak Berkebutuhan Khusus. Bogor: Program Studi Pendidikan Guru Sekolah Dasar Universitas Pakuan

[8] Fadhli,Aulia. 2010. Buku Pintar Kesehatan Anak. Yogyakarta: Penerbit Pustaka Anggrek

[9] Widyorini, Endang dan Julia Maria van Tiel. 2017. DISLEKSIA (Deteksi Diagnosis Penanganan di Sekolah dan di Rumah). Jakarta: Prenada

[10] Suryani, Erma Yulinda. 2010. Kesulitan Belajar. Dalam Jurnal Magistra No. 73

[11] Arisandi, Elisa. 2014. Meningkatkan Kemampuan Operasi Perkalian Untuk Anak Diskalkulia Melalui Metode Garismatika. Dalam Jurnal Ilmiah Pendidikan Khusus, vol 3(3).

[12] Winarsih. 2013.Upaya Guru Dalam Mengatasi Kesulitan BelajarMembaca,Menulis dan Berhitung (CALISTUNG) Pada Siswa Kelas 1 SD Negeri Jatiroto,Wonosari, Purwosari, Girimulyo, Kulon Progo. Skripsi Program Studi Pendidikan Guru Madrasah Ibtidaiyah Universitas Islam Negeri Kalijaga Yogyakarta

[13] Mutiani,Ria dan Suyadi Suyadi. 2020. Diagnosa Diskalkulia Generasi Alpha: Masalah dan Perkembangan. Dalam Jurnal Pendidikan, vol 4 (1)

[14] Bastari,Elvina. 2019. Hubungan Motivasi Belajar Dengan Hasil Belajar Peserta Didik Pada Mata
Pelajaran IPS Kelas IV SD Negeri 1 Sukabumi Indah Bandar Lampung. Skripsi Pendidikan Guru Madrasah Ibtidaiyah (PGMI) Universitas Islam Negeri Raden Intan Lampung

[15] Pamungkas, Bayu dan Padrul Jana. 2018. Siswa Kesulitan Belajar Menghitung (Dyskalkulia) Pada Mata Pelajaran Matematika. Dalam Jurnal Abdi Masyarakat, vol 1(2)

[16] Savira, Ulia Savira. 2019. Teknik Reinforcement Untuk Meningkatkan Motivasi Pada Anak Tunagrahita yang Mengalami Kesulitan Menghitung (dyscalculia learning) di SDN Bendul Merisi 408 Surabaya. Dalam Skripsi Program Studi Bimbingan dan Konseling Islam Surabaya

[17] Ernata,Yusvida. 2017. Analisis Motivasi Belajar Peserta Didik Melalui Pemberian Reward dan Punishment di SDN Ngaringan 5 Kec.Gandusari Kab.Blitar. Dalam Jurnal Pemikiran dan Pengembangan SD, vol 5(2).

[18] Mardika,Tiwi. 2017. Analisis Faktor- faktor Kesulitan Membaca, Menulis dan Berhitung Siswa Kelas 1 SD. Dalam Jurnal Dinamika Pendidikan Dasar, vol 10 (1) 